\title{
Samarbejde - kooperation eller kollaboration?
}

\author{
Jørgen Bang \\ Lektor, mag.art. \\ Institut for Informations- og Medievidenskab \\ Aarhus Universitet \\ jbang@imv.au.dk
}

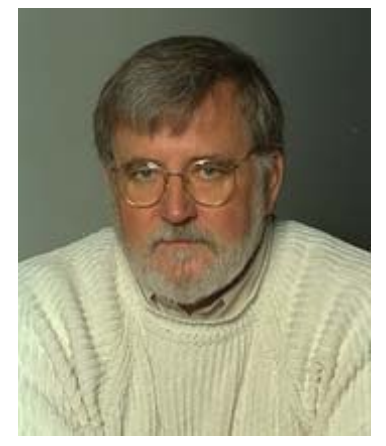

\section{Christian Dalsgaard}

Ph.d.-studerende, cand.mag.

Institut for Informations- og Medievidenskab

Aarhus Universitet

cnd@imv.au.dk



Jørgen Bang er lektor ved Institut for Informations- og Medievidenskab, Aarhus Universitet, og formand for universitetets udvalg for åben uddannelse. På internationalt plan har han deltaget i adskillige EU-projekter, væeret formand for nordisk forum for datastøttet læring (1991-95) og er siden januar 2002 president for European Association for Distance Teaching Universities EADTU). Har publiceret bøger og artikler inden for emnerne nordisk litteratur, fortælleformer, ediereception, kommunikation i elektroniske netværk, læringsteori og undervisningsteknologi.

Christian Dalsgaard er ph.d.-studerende ved Institut for Informations- og Medievidenskab, Aarhus Universitet. Han forsker i, hvordan it-baserede lceringsmaterialer kan udvikles med udgangspunkt i et leringsteoretisk fundament. Derudover har han blandt andet arbejdet med pæedagogisk vurdering af e-lceringssystemer og lceringsobjekter.

\section{Optakt}

Centralt for diskussionen af samarbejdssystemer på nettet til støtte for læreprocesser er spørgsmålet om hvordan samarbejdet er organiseret. I denne artikel lancerer vi en skelnen mellem samarbejde som kooperation og som kollaboration med henblik på en diskussion af hvilken form for samarbejde, der egner sig bedst til læring og vidensdeling. En skelnen mellem kooperativt og kollaborativt samarbejde ligger ikke lige for i det danske normalsprog, men er hentet fra engelsk hvor det danske 'sam' defineres som enten 'cooperative' eller 'collaborative'.

Artiklen argumenterer for, at et kooperativt samarbejde indebærer en kognitivistisk opfattelse af læring som overførsel af viden, mens et kollaborativt samarbejde støtter en socialkonstruktivistisk opfattelse af læring som en fælles konstruktion af viden. I forlængelse heraf ønkser vi med artiklen at rejse en diskussion af om ikke kollaborativt samarbejde indebærer et højere lærings- og bevidsthedsniveau end kooperation. 
Sidst men ikke mindst argumenterer vi i artiklen for , at samarbejdssystemer til støtte af kollaboration kræver et fokusskifte fra lagring og udveksling af dokumenter til støtte af de aktiviteter, hvori deltagerne i fællesskab konstruerer viden.

\section{Er samarbejde kooperativt eller kollaborativt?}

I artiklen "The construction of shared knowledge in collaborative problem solving" giver Roschelle \& Teasley (1995: 70) følgende definition på forskellen kollaborativt og kooperativt samarbejde:
"We make a distinction between 'collaborative' versus ‘cooperative’ problem solving. Cooperative work is accomplished by the division of labour among par- ticipants, as an activity where each person is responsible for a portion of the prob- lem solving. We focus on collaboration as the mutual engagement of participants in a coordinated effort to solve the problem together.”

Denne forskel mellem kooperation og kollaboration er ifølge Dillenbourg et al. (1996) ikke et spørgsmål om, at arbejdsopgaven er distribueret eller ikke, men derimod et spørgsmål om, hvordan opgaven er delt. I et kooperativt samarbejde inddeles opgaven ifølge Dillenbourg et al. i uafhængige delopgaver, mens opgaverne i et kollaborativt arbejde er vævet ind i hinanden.

Ved kooperation forstås således et samarbejde, hvor en arbejdsopgave inddeles i mindre delopgaver, som uddelegeres til deltagerne, der arbejder på dem uafhængigt af hinanden. Det betyder, at deltagerne i denne form for samarbejde arbejder med forskellige og uafhængige målsætninger. Det er derfor ikke nødvendigt for deltagerne at vide, hvad de andre beskæftiger sig med. Når deltagerne har afsluttet hver deres delopgaver, er den samlede opgave også løst. Det vil sige, at kooperative processer indebærer arbejdsdeling og koordinering af arbejdsopgaverne. I et kooperativt samarbejde er det derfor nødvendigt med en præcis afgrænsning af ansvarsområderne.

I modsætning hertil forstås kollaboration som et samarbejde, hvor deltagerne er fælles om at løse en arbejdsopgave. Deltagerne arbejder sammen mod et fælles mål og er indbyrdes afhængige. Idet deltagerne indgår i et fællesskab, gennemgår de i princippet de samme processer - det vil sige, at alle i princippet ved det samme. Det væsentlige er, at deltagerne besidder en fælles opfattelse af arbejdsopgaven.

"Collaboration is a coordinated, synchronous activity that is the result of a continued attempt to construct and maintain a shared conception of a problem." (Roschelle \& Teasley 1995: 70)

Dette synspunkt præciseres yderligere hos Heilesen (2002: 80):

"Kollaborativt arbejde er kendetegnet ved, at flere personer i fællesskab og med fælles målsætning løser en opgave, samt at medlemmerne af arbejdsfællesskabet er gensidigt afhængige af hinanden og føler et gensidigt ansvar.”

I det kollaborative samarbejde skal der skabes et fællesskab, hvori opgaven løses. Derfor kræves der en høj grad af udveksling og kommunikation mellem deltagerne i et kollaborativt samarbejde. 
“... we argue that collaborative problem solving takes place in a negotiated and shared conceptual space, constructed through the external mediational framework of shared language, situation, and activity ...” (Roschelle \& Teasley 1995: 70)

Det betyder samtidig, at kollaboration kræver en høj grad af løbende koordination mellem deltagerne. Roschelle \& Teasley (1995) taler direkte om et Joint Problem Space: "collaboration as a process of constructing and maintaining a Joint Problem Space”.

I nedenstående figur har vi forsøgt at tydeliggøre en række forskelle mellem kooperativt og kollaborativt samarbejde:

\begin{tabular}{|l|c|c|}
\hline & Kooperation & Kollaboration \\
\hline Opgaven & $\begin{array}{c}\text { (Ud)deling af opgaver } \\
\text { Forskellige målsætninger } \\
\text { Afgrænsning af ansvarsområder }\end{array}$ & $\begin{array}{c}\text { Fælles opgave } \\
\text { Fælles målsætning } \\
\text { Fælleshed / fællesskab }\end{array}$ \\
\hline Arbejdet & $\begin{array}{c}\text { Lukkede arbejdsopgaver } \\
\text { Forudsigelige processer } \\
\text { Statisk }\end{array}$ & $\begin{array}{c}\text { Åbne arbejdsopgaver } \\
\text { Uforudsigelige processer } \\
\text { Dynamisk }\end{array}$ \\
\hline Produktet & $\begin{array}{c}\text { Produktion } \\
\text { Kendt produkt }\end{array}$ & $\begin{array}{c}\text { Udvikling } \\
\text { Nyt produkt }\end{array}$ \\
\hline $\begin{array}{l}\text { Deltagernes relati- } \\
\text { oner }\end{array}$ & $\begin{array}{c}\text { Indbyrdes uafhængighed } \\
\text { Adskilt (asynkron) opgaveløsning } \\
\text { Forskellige kontekster }\end{array}$ & $\begin{array}{c}\text { Gensidig afhængighed } \\
\text { Fælles (synkron) opgaveløsning } \\
\text { Fælles kontekst }\end{array}$ \\
\hline
\end{tabular}

Figur 1. Kooperation vs. Kollaboration

Idet en kooperativ arbejdsopgave skal opdeles og afgrænses, forudsætter kooperation et kendskab til udformningen af det færdige produkt samt en vis indsigt i arbejdsprocesserne. En vis forudsigelighed er derfor forbundet med et kooperativt samarbejde. I modsætning hertil retter kollaboration sig i høj grad mod mere åbne arbejdsopgaver (såsom udviklingsprojekter) og uforudsigelige processer. Det skyldes, at arbejdsopgaven ikke på forhånd er fastlagt og inddelt i delopgaver. Samtidig udvikles det samlede projekt i fællesskab, hvorfor det konstant er muligt at bevæge arbejdet i nye retninger - løsningen er ikke fastsat på forhånd. Med andre ord forudsætter et kollaborativt samarbejde ikke, at deltagerne præcist ved, hvad de skal fremstille, eller hvordan de skal gøre det. Derfor kan et kollaborativt samarbejde betegnes som en udviklingsmodel, hvor fokus er på selve udviklingsprocessen.

\section{Kooperativt arbejde, men kollaborativ læring}

Inden for forskningsfeltet CSCW - Computer Supported Cooperative Work - defineres samarbejde som kooperativt, mens læring inden for det parallelle forskningsfelt CSCL - Computer Supported Collaborative Learning - defineres som kollaborativ. Hvorfor denne forskel?

Tager vi udgangspunkt i ovenstående sondring mellem kooperative og kollaborative arbejdsprocesser kan en forklaring måske findes i arbejdsbegrebets historiske udvikling. I den førindustrielle periode var arbejdet organisk bundet til døgnets og årstidens rytme eller - hvis vi fokuserer specifikt på håndværket - til bestillingsopgaver, hvor skrædderen, snedkeren eller 
smeden aftalte at producere en brugsgenstand efter regning. Med industrialiseringen sættes vareproduktionen i system, så der produceres til lager med henblik på senere salg til kunder. Dermed bliver det også afgørende at reducere produktionsomkostningerne ved at rationalisere produktionsprocessen. Med samlebåndproduktionen sætter Henry Ford for alvor en ny produktionsfilosofi på dagsordenen. Langt hen kan det kooperative arbejde ses som en aflægger af 'fordismen', hvor den samlede arbejdsproces opdeles i enkelte operationer - delopgaver som så til sidst samles til et færdigt produkt. Den enkelte arbejder, som udfører en afgrænset opgave eller producerer en delkomponent til helheden, behøver ikke at kende slutproduktet i detaljer. Arbejdsprocessen er tilrettelagt af ledelsen.

Industrialismens produktionsform er uden tvivl effektiv og rationel ud fra en økonomisk betragtning, men ikke alt arbejde kan tilrettelægges ud fra 'fordismens' logik. Institutioner som f.eks. sygehuse og skoler forudsætter en anden grad af samarbejde mellem personalegrupper med forskellige kvalifikationer for at fungere optimalt. Her er der behov for kollaboration. (Dourish, Paul o.a. 2004 er udbygger denne problemstilling i et tidsligt perspektiv).

En sammenligning fra sportens verden kan måske tydeliggøre vores pointe. Industrialismens produktionsform kan sammenlignes med stafetløbet, hvor den enkelte deltager bidrager med sin optimerede solopræstation til holdets samlede præstation, mens sygehuse og skoler - og i stor udstrækning også den postindustrielle arbejdsorganisering - kan sammenlignes med holdsport som fodbold og håndbold, hvor den enkelte deltager skal aflæse spillet og definere sin rolle i forhold til medspillerne.

Betragtes kooperation og kollaboration derfor som modeller for produktion har de begge en berettigelse. Karakteren af produktionen afgør, om det er mest hensigtsmæssigt at inddele den i delopgaver, eller om det er nødvendigt at løse den i fællesskab, og desuden vil en given produktion ofte bestå i forskellige grader af kooperation og kollaboration.

Jo mere videnstung en produktion er, jo større forekommer behovet for kollaborativt samarbejde. Når det drejer sig om læreprocesser, er der tale om vidensudvikling, som for at kunne foregå optimalt i samarbejde med andre må etableres på kollaborative præmisser. Derfor definerer CSCL traditionen samarbejde om læring som 'collaborative learning'.

Desværre er ikke al samarbejde om læring kollaborativt per definition. Utallige er eksemplerne på gruppeopgaver som er blevet løst ud fra en kooperativ tilgang: Opgaven er i udgangssituationen blevet delt mellem gruppens medlemmer. Et eksempel kan måske bedre end mange ord illustrere, hvad vi tænker på. Hvis en gruppe på fire får til opgave at give en karakteristik af H.C. Andersens eventyr ud fra udvalgte eventyr, løser de ofte opgaven ved at hver person analyserer og karakteriserer ét eventyr, som efterfølgende præsenteres mundtligt eller skriftligt i forlængelse af hinanden. Resultatet er, at gruppens medlemmer hver kender ét og kun ét eventyr. En kollaborativ løsning på denne opgave ville være, at hele gruppen læser alle fire eventyr, analyserer og diskuterer dem samt uddrager karakteristiska vedrørende genren og H.C. Andersens omverdensforståelse for derefter at fordele præsentationen mellem sig mundtligt eller skriftligt.

\section{Konsekvenser for vidensdeling}

I en samarbejdsproces kræves det, at deltagerne deler viden med hinanden. Det finder sted på forskellige måder i henholdsvis kooperation og kollaboration. Der er med andre ord forskel på karakteren af den vidensdeling, der finder sted i de to former for samarbejde. Vidensdeling skal her forstås i betydningen af at udveksle viden med hinanden. 
I kooperation er vidensdeling begrænset, idet deltagerne anvender viden i forskellige kontekster. Deltagerne arbejder med forskellige områder og udveksler/deler deres resultater med de øvrige deltagere. Der er tale om færdige leverancer, som de øvrige deltagere skal bruge i en anden kontekst. I princippet er det ikke nødvendigt for den enkelte deltager at vide, hvad de andre foretager sig og skal bruge det leverede til. Eftersom arbejdsopgaven er uddelegeret $\mathrm{i}$ uafhængige delopgaver, spiller vidensdeling ikke en stor rolle i et kooperativt samarbejde.

I modsætning hertil er vidensdeling afgørende for et kollaborativt samarbejde. Det skyldes, at deltagerne skal dele alt med hinanden. Alle skal have samme forståelse for arbejdet. Samtidig indebærer kollaboration, at viden anvendes af deltagerne på samme måde i samme kontekst. Viden har samme fælles betydning for samtlige deltagere. Vidensdeling er ikke et spørgsmål om at "udveksle med hinanden”, men derimod om at "være fælles om”. Derfor består vidensdeling primært i deltagelse i samme processer. Det er muligt at have forskellige roller i et kollaborativt samarbejde, men deltagerne vil altid være fælles om målet.

Det betyder, at kooperation indebærer vidensdeling i en traditionel forstand. Det vil sige vidensdeling i betydningen af, at man deler ud af eller overdrager viden til andre. Derimod er der i kollaborativ vidensdeling tale om, at man i tilknytning til et fælles arbejde løbende delagtiggør andre i sit arbejde samt i sine tanker og idéer.

Kooperation og kollaboration skal ikke forstås som rene former for samarbejde og vidensdeling, og de udelukker ikke hinanden. I stedet kan man tale om grader af kooperation og kollaboration i en given form for samarbejde. Man kan se kooperative og kollaborative samarbejdsprocesser som punkter på et kontinuum, der går fra individuelt arbejde over kooperativt samarbejde til kollaborativt samarbejde.

Nu er fokus for denne artikel ikke spørgsmålet om, hvilken form for samarbejde der egner sig bedst til en given produktion, men derimod, hvilken form for samarbejde, der egner sig bedst til læring og vidensdeling. Hvor høj grad af henholdsvis kooperation og kollaboration er frugtbart?

I det følgende vil vi inddrage det 20. århundredes to dominerende læringsteoretiske forståelsesformer: kognitivismen og socialkonstruktivismen i diskussionen af samarbejdsformerne med henblik på at placere kooperation og kollaboration som bevidsthedsformer.

\section{Kognitivistisk og socialkonstruktivistisk syn på vidensdeling og samar- bejde}

Kognitivisme og socialkonstruktivisme repræsenterer to forskellige læringsteoretiske syn på vidensdeling og på samarbejdes betydning for læring. I figur 2 har vi forsøgt at skitsere nogle fundamentale forskelle mellem en kognitivistisk og en socialkonstruktivistisk forståelse.

\begin{tabular}{|l|c|c|}
\hline & Kognitivisme & Socialkonstruktivisme \\
\hline Mennesket & Individuelt & Socialt \\
\hline Viden & Objektiv information & Social konstruktion \\
\hline Læring & Informationsbehandling & Anvendelse af social praksis \\
\hline Vidensdeling & Overførsel & Deling af social praksis \\
\hline
\end{tabular}

Figur 2. Kognitivisme vs. socialkonstruktivisme 


\section{Kognitivisme}

En kognitivistisk forståelse af læring tager udgangspunkt i individet og fokuserer på individets evner til at modtage og behandle stimulus gennem sanserne. Intelligensbegrebet i Howard Gardners teori om de mange intelligenser er udviklet ud fra en kognitivistisk forståelse:

"One might go so far as to define a human intelligence as a neural mechanism or computational system which is genetically programmed to be activated or "triggered” by certain kinds of internally or externally presented information.” (Gardner 1983: 64)

Gardners tilgang indebærer, at læring forstås som modtagelse og behandling af objektiv information, der er uafhængig af mennesket. Dermed bygger Gardner på et objektivistisk vidensbegreb - viden kan objektiviseres. Den kognitivistiske tilgang har en individualistisk forståelse af læring, idet mennesket lærer gennem individuel behandling af information. Med andre ord finder læring sted i hovedet på individet. (Se Dalsgaard 2004 for en uddybning af den kognitivistiske tilgang.)

Den kognitivistiske forståelse indebærer, at samarbejde som udgangspunkt ikke er en forudsætning for læring og vidensdeling, eftersom læring er individuel behandling af objektiv information. Det udelukker dog ikke, at samarbejde kan styrke læring, men der er tale om samarbejde i en bestemt betydning. Samarbejde kan relateres til læring ud fra tre forskellige betydninger; samarbejde som læringsmål, læringsstil eller som vidensdeling.

Samarbejde som læringsmål kan findes hos Gardner (1983; 1993), der definerer én af de mange intelligenser som "interpersonal intelligence". Denne intelligens beskriver individets evne til at begå sig blandt andre mennesker, hvilket blandt andet vil indeholde evnen til at samarbejde. Derudover kan samarbejde betragtes som en læringsstil, det vil sige som en måde at lære på. Ifølge Dunn (2003) bestemmes en læringsstil af individets præferencer for en række stimuli, der skaber de rette forudsætninger for et individs læring. De rette stimuli fjerner den "støj”, der hindrer det enkelte individs informationsbehandling. Blandt de forskellige stimuli findes sociologiske stimuli, der blandt andet indbefatter forskellige former for samarbejde. Det betyder, at samarbejde hos nogle er eller kan være én blandt flere stimuli, der medvirker til at skabe de rette forudsætninger for læring.

Endelig kan samarbejde styrke læring gennem vidensdeling, idet man i et samarbejde kan lære af hinanden ved at dele viden. Den kognitivistiske forståelse indebærer, at viden kan ekspliciteres gennem information. Ifølge Gardner (1983) er det muligt at transmittere information mellem mennesker og dermed overføre viden. Viden er uafhængig af og kan separeres fra afsenderen og fra en given kontekst. Med andre ord er vidensdeling et spørgsmål om at overføre viden. Samarbejde i denne betydning af at uddele og overføre viden betegner en form for kooperation. Dermed lægger den kognitivistiske tilgang sig op ad en traditionel forståelse af vidensdeling som 'knowledge management'. Ifølge denne forståelse kan viden lagres, organiseres, administreres, leveres og modtages. (Se Bang 2004 for en uddybning af kognitivistisk vidensdeling.)

Samarbejde kan derfor tjene forskellige formål, men det skal understreges, at samarbejde inden for en kognitivistisk forståelse ikke er en forudsætning eller nødvendighed for læring.

\section{Socialkonstruktivisme}

Den socialkonstruktivistiske læringstradition har været medvirkende til at sætte fokus på samarbejdets betydning for læring. Socialkonstruktivismens fokus på samarbejde udspringer af en 
opfattelse af læring som en social aktivitet, der er situeret i en praktisk kontekst. Især Vygotsky har haft stor betydning for denne teoriudvikling (Bannon 1995; O’Malley 1995):

"Udviklingsprocessens retning går fra det sociale til det individuelle og ikke fra det individuelle til det socialiserede [...]” (Vygotsky 1971a: 59)

Ifølge Vygotsky (1971a; 1971b; 1978) er mennesket først og fremmest socialt, og tænkning har sin oprindelse i det sociale. I modsætning til kognitivismen betragtes viden som en social konstruktion, hvilket betyder, at viden konstrueres af menneskene i konstruktionen af en social praksis. Ifølge en socialkonstruktivistisk forståelse finder læring ikke blot sted i sociale sammenhænge, men viden er tilmed bundet i den sociale kontekst. Med betegnelsen "situeret læring” mener Lave og Wenger (1991), at viden ikke består af kontekstuafhængige facts, men i stedet knytter sig til en hel situation, det vil sige til handlinger i en praksis. Mere præcist finder situeret læring sted gennem deltagelse i praksisfællesskaber (Wenger 1998). (Se Dalsgaard 2004 for en uddybning af den socialkonstruktivistiske tilgang i form af virksomhedsteori.)

Den socialkonstruktivistiske forståelse indebærer som udgangspunkt, at samarbejde i relation til læring og vidensdeling er betydningsfuld i forhold til den sociale kontekst, der danner rammen om samarbejdet. Ifølge en socialkonstruktivistisk forståelse finder læring sted i en eller anden form for kollaboration, hvor deltagerne tager del i et fælles arbejde. Det er imidlertid kollaboration i en bestemt betydning og med vægten lagt på bestemte aspekter. Det skyldes først og fremmest, at læring ifølge en socialkonstruktivistisk forståelse ikke er individuel, eftersom viden alene eksisterer i sociale sammenhænge.

"Knowing is inherent in the growth and transformation of identities and it is located in relations among practitioners, their practice, the artifacts of that practice, and the social organization and political economy of communities of practice.” (Lave \& Wenger 1991: 122)

Som udgangspunkt er samarbejde i tilknytning til læring og vidensdeling således ikke et spørgsmål om blot at arbejde sammen, men nærmere et spørgsmål om at deltage i en social kontekst. Derfor bliver arbejdsopgaven og den sociale praksis afgørende for samarbejdets betydning for læring og vidensdeling. I modsætning til kognitivisme er samarbejde med andre ord ikke et middel til at igangsætte og effektivisere bestemte processer, men derimod en integreret del af læreprocessen.

Det centrale for den socialkonstruktivistiske forståelse er, at læring og vidensdeling finder sted i en social kontekst, der er fcelles for deltagerne. Der er dog ikke enighed blandt socialkonstruktivistiske retninger om, hvad det fælles består i. Selve den fysiske praksis står centralt i Lave \& Wengers opfattelse af læring, idet læring betragtes som en form for socialisering ind i et praksisfællesskab, hvis konstruktion besidder eller indeholder viden. Virksomhedsteorien i form af Leontjev (1983) og Engeström (1987) lægger ligeledes vægt på menneskenes deltagelse i et fællesskab. Men med betegnelsen kollektiv aktivitet understreger de samtidig, at menneskets mål og motiver er centrale for menneskets aktivitet. Væsentlige forudsætninger for læring og vidensdeling kan derfor siges at være et fællesskab, der konstrueres på baggrund af:

- fælles social kontekst

- fælles målsætning 
Eftersom læring finder sted i en social kontekst, og eftersom viden er bundet i en kontekst, er det nødvendigt, at den enkelte deltager ikke blot beskæftiger sig med et udsnit af arbejdet. Det er nødvendigt at have indsigt i hele processen, i hele praksisen. Betydning og dermed også individets forståelse ligger i den samlede, fælles praksis. Derfor forsvinder betydningen og forståelsen, hvis praksisen splittes op. Det fælles kan derfor ikke skabes gennem et kooperativt arbejde, men kræver en vis grad af kollaboration. Den enkelte deltager skal ikke blot stå for et udsnit af det samlede produkt, men skal involveres i og have en forståelse for hele produktet. Det betyder, at der ikke er tale om kooperation, men omvendt heller ikke en radikal form for kollaboration.

Læring er ikke blot et spørgsmål om at sætte personer til at samarbejde, men et spørgsmål om at opbygge en fælles social kontekst omkring en fælles målsætning. Kollaborativt arbejde er derfor ikke nødvendigvis en afgørende forudsætning for læring, men man kan omvendt sige, at en vis grad af kollaboration kan være medvirkende til at skabe det fælles.

Det betyder samtidig, at vidensdeling kun er frugtbar, når deltagerne er engageret i et fælles arbejde og giver hinanden input til samme kontekst. Vidensdeling kan således fostres ved at skabe et fællesskab, der anvender viden i relation til samme formål. Et fælles engagement i et arbejde skaber forudsætningerne for, at deltagerne forstår hinanden. Skabes i modsætning hertil en høj grad af arbejdsdeling, forringes mulighederne for vidensdeling.

"Individuals do not even compose a social group because they all work for a common end. The parts of a machine work with a maximum of cooperativeness for a common result, but they do not form a community. If, however, they were all cognizant of the common end and all interested in it so that they regulated their specific activity in view of it, then they would form a community. But this would involve communication.” (Dewey 1916: 5)

Et kooperativt samarbejde i betydningen af at dele eller udveksle viden med hinanden på tværs af kontekst vil med andre ord begrænse mulighederne for vidensdeling og læring. En socialkonstruktivistisk tilgang kræver derfor et alternativ til den kognitivistiske knowledge management. Alternativet skal styrke en vis grad af kollaborativt samarbejde, der i højere grad kan medvirke til at konstruere et fælles arbejde. Modsat kooperation styrkes et kollaborativt samarbejde gennem en dynamisk og konstruktiv form for vidensdeling, der indebærer en høj grad af kommunikation og interaktion.

\section{Kooperation og kollaboration som forskellige bevidsthedsniveauer}

Ud fra Engeströms (1987) kobling af Batesons læringsniveauer med Leontjevs virksomhedsteori (på engelsk 'Activity Theory') vil vi forsøge at foretage en niveaudeling af kooperation og kollaboration i relation til læring. Ifølge denne niveaudeling forudsætter kooperation og kollaboration forskellige bevidsthedsniveauer.

Engeström (1987) tager udgangspunkt i Leontjevs inddeling af menneskets aktivitet i tre niveauer: virksomhed, handling og operation. Ifølge Leontjev (1983) betegner begrebet virksomhed menneskenes kollektive aktivitet, en handling udgør menneskets individuelle aktivitet, mens operationer beskriver de fysiske bevægelser, der i sidste ende udfører aktiviteten. De tre dimensioner af menneskets aktivitet hænger sammen men udgør forskellige niveauer i den forstand, at operationer tjener handlinger, der tjener den overordnede virksomhed. En virksomhed er rettet mod et overordnet motiv, der er betydningsbærende for hele aktiviteten, og alle handlinger og operationer tjener i sidste ende dette motiv. En handling er imidlertid rettet mod et mål, der ikke direkte retter sig mod motivet. I stedet udgør handlingens mål en delopgave, der sammen med øvrige mål opfylder motivet. 
Et rent illustrativt eksempel er, at konstruktionen af et stoleben ikke direkte retter sig mod et motiv om at konstruere en stol, men derimod mod et mål om at udforme en lang rund pind. Det betyder, at motivet "forsvinder" i målene. Det vil sige, at det er muligt at udføre handlingen - lave stolebenet - uden at have kendskab til stolens udformning. En virksomhed kan med andre ord udføres gennem et kooperativt samarbejde, hvor handlinger uddeles til aktivitetens deltagere.

I Engeströms betydning af læringsniveauerne forudsætter læring udvikling af en aktivitet, hvorfor Engeström definerer Læring I, II og III som ændringer af henholdsvis operationer, handlinger og virksomheden (Batesons teori inkluderer også Læring O og IV, men de anvendes ikke af Engeström). Det indebærer, at der i Læring III er tale om kollektiv læring, hvorfor et individ ikke kan lære på niveau III. Men individet kan være bevidst om dette niveau. Derfor kan det i stedet være hensigtsmæssigt at tale om bevidsthedsniveauer (se også Qvortrup 2001, der taler om forskellige vidensniveauer). Således vil niveau I, II og III indebære en bevidsthed om henholdsvis operationer, handlinger og virksomheden.

Som nævnt kan en virksomhed udføres gennem et kooperativt samarbejde, der hos de enkelte individer forudsætter en bevidsthed om niveau I og II. Forståelsen for en virksomhed forudsætter imidlertid en bevidsthed om niveau III, hvilket indebærer en indsigt i de øvrige handlinger og i virksomhedens motiv. Det skyldes, at operationer har betydning i relation til handlinger, der igen har betydning i relation til en virksomhed. Niveau III giver med andre ord et højere niveau af forståelse for handlinger og operationer. Det vil samtidig sige, at niveauerne udgør forskellige refleksionsniveauer. Niveau III giver mulighed for at reflektere over handlingerne i relation til det overordnede motiv, hvorfor eksempelvis stolebensproducenten bliver i stand til at sætte spørgsmålstegn ved, om stole overhovedet kræver stoleben, eller om det er muligt at lave en anderledes konstruktion.

Selvom et kooperativt arbejde derfor er i stand til at udføre en virksomhed, skaber det ikke forudsætningerne for at udvikle virksomheden. Det skyldes, at det kooperative arbejde indebærer, at deltagerne ikke får en fuldstændig forståelse for virksomheden på niveau III. Udviklingen af en virksomhed - og ikke mindst konstruktionen af en ny - kræver en bevidsthed om niveau I, II og III. Et kollaborativt samarbejde forudsætter netop, at deltagerne opnår forståelse for og indsigt i hele virksomheden og dermed har bevidsthed om niveau III.

Figur 3 forsøger at opsummere sammenhængene:

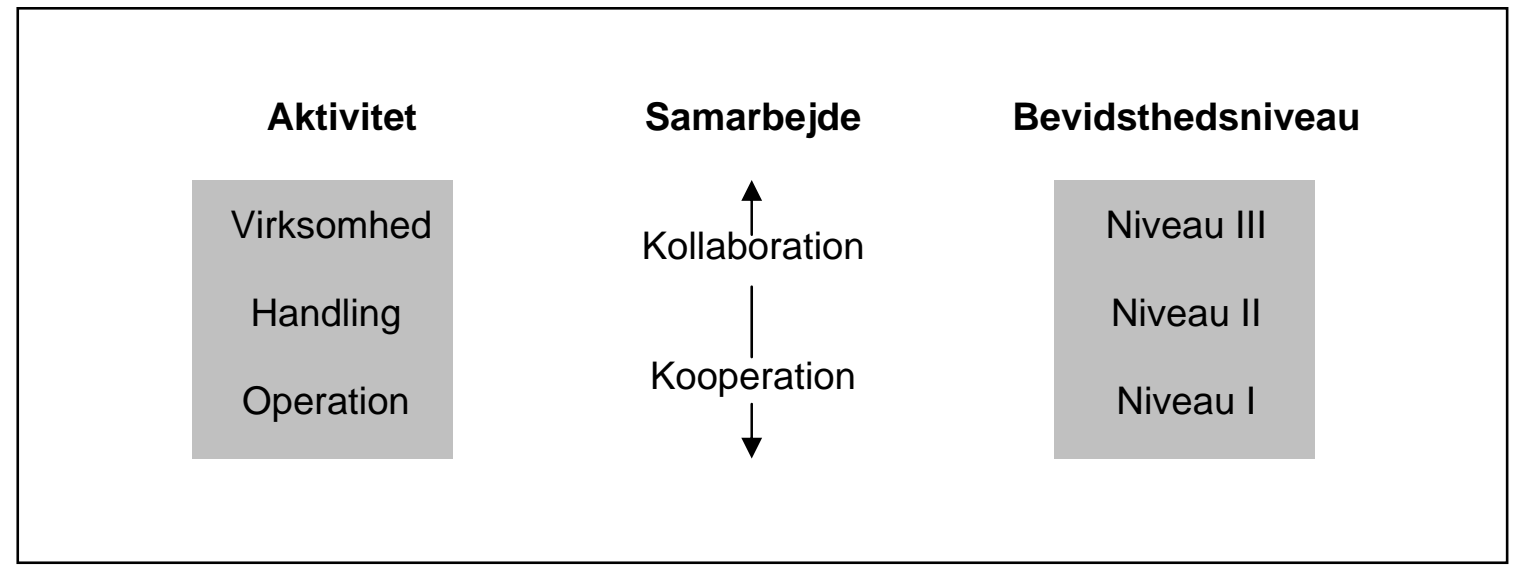

Figur 3. Niveaudeling af kooperation og kooperation 


\section{Fra knowledge management til knowledge construction}

Niveaudelingen af kooperation og kollaboration afføder et ønske om at fremme kollaborativt samarbejde inden for vidensdeling og læring. Spørgsmålet er, hvilke krav kollaboration stiller til samarbejdssystemer. Eksisterende samarbejdssystemer understøtter i høj grad traditionel knowledge management og dermed kooperativt samarbejde. Mange af systemerne bygger på idéen om, at viden kan overføres, og derfor støtter systemerne primært lagring, administration og udveksling af viden i form af eksempelvis dokumenter. Et kollaborativt samarbejde stiller nye krav til samarbejdssystemer. Understøttelsen af kollaborative læreprocesser kræver, at samarbejdssystemer bevæger sig fra en idé om 'knowledge management' til en idé om 'knowledge construction'.

Idéen om knowledge construction betyder, at et samarbejdssystem ikke skal fungere som et sted, hvor viden lagres og administreres, men i stedet som et sted, hvor viden løbende konstrueres af deltagerne i samarbejdet. Det skyldes, at kollaborative samarbejdsprocesser først og fremmest indebærer, at fokus flyttes fra den "viden”, der er lagret og lagres i systemet, og i stedet placeres på de kollaborative aktiviteter, hvori deltagerne konstruerer viden i systemet. Lagring eller udveksling bliver sekundært til deltagernes løbende samarbejde. Det betyder, at et kollaborativt samarbejde støttes af systemer, der ikke er baseret på statisk lagring, men derimod på dynamisk rekonstruktion og viderebearbejdning. Bevægelsen fra knowledge management til knowledge construction indebærer, at systemer skal fungere som støtte for aktiviteter sideordnet med at de fungerer som lager af viden.

Denne problematik træder meget tydeligt frem i den følgeforskning (Bang, Dalsgaard \& Kjær 2004), som blev gennemført i tilknytning til ITMF-projekt 386: Vidensdeling ved hjœelp af intranet. I projektet anvendte lærere på fire folkeskoler et vidensdelingssystem til at samarbejde om og dele undervisningsforløb; men de havde dårlige erfaringer med deling af færdige undervisningsforløb, der blev lagret i systemet. Derimod havde lærerne succes med at arbejde med procesorienterede logbøger, hvori lærerne løbende skrev videre på hinandens indlæg og dermed konstruerede undervisningssamarbejde i fællesskab. Projektet viser, at vidensdeling mellem lærere ikke primært er et spørgsmål om deling af færdige undervisningsforløb og materialer. I stedet er konklusionen, at en konstruktiv vidensdeling i højere grad handler om kommunikation og samarbejde mellem lærerne.

"For at tage skridtet til vidensdeling skal lærerne indarbejde arbejdsprocesser, hvor de ikke blot anvender hinandens redskaber [idéer, tanker, materialer, opgaver, erfaringer, etc.], men hvor de knytter kommentarer ikke kun til egne men til andres redskaber og diskuterer dem. Det betyder for det første, at bøger kan få vedhæftet flere kommentarer, en given hjemmeside kan anbefales i tilknytning til forskellige områder, etc. For det andet betyder det, at lærerne skal indarbejde arbejdsprocesser, hvor de stiller spørgsmål til hinanden samt til hinandens redskaber. [...] Derfor styrkes vidensdelingen, hvis lærerne spørger til og diskuterer hinandens redskaber. Dermed er der tale om samarbejde mellem lærere.” (Bang, Dalsgaard \& Kjær 2004: 53)

Som udgangspunkt skal et samarbejdssystem til støtte af kollaboration fungere som et samlingssted, der danner rammen om arbejdet med en fælles målsætning. Systemet skal fungere som det sted, hvor viden løbende konstrueres og rekonstrueres. Det indebærer, at systemet skal give muligheder for en høj grad af kommunikation og interaktion i form af diskussioner, dialog, kommunikation, kommentarer, spørgsmål, etc. Deltagerne skal eksempelvis have mulighed for at dele ufærdige og midlertidige resultater, tanker, idéer, udkast og spørgsmål, der løbende arbejdes videre med. Deltagerne skal kunne skrive videre på hinandens meddelelser, skrive oven i hinandens dokumenter, knytte kommentarer til indlæg, stille spørgsmål og lig- 
nende. En sådan løbende udvikling vil være medvirkende til at skabe en fælles kontekst omkring det kollaborative arbejde.

Dette indebærer, at udvikling af systemer til støtte af kollaborativt samarbejde - som det er beskrevet i denne artikel - kræver et markant anderledes syn på samarbejdssystemer og deres funktion i relation til vidensdeling og læring. Selvom eksisterende systemer i nogen grad tilbyder funktioner til støtte af en dynamisk form for samarbejde, er der ikke desto mindre behov for en målrettet indsats for udvikling af samarbejdssystemer, der støtter kollaborativt samarbejde. Der er behov for at tænke i radikalt anderledes baner. I stedet for et fokus på lagring, udveksling og overførsel skal udgangspunktet for udvikling af samarbejdssystemer være opbygningen af en fælles kontekst, hvori viden konstant diskuteres, viderebearbejdes og rekonstrueres.

\section{Litteratur}

Bang, Jørgen, Dalsgaard, Christian \& Kjær, Arne. Vidensdeling ved hjælp af IT i folkeskolen. Forskningsprojekt i tilknytning til ITMF-projekt 386: Vidensdeling ved hjælp af intranet. 2004. <http://www.imv.au.dk/forskning/cil/forskningsprojekter/afsluttedegrundskole.html $>$ (15.2.2005)

Bang, Jørgen. ”Hvorfor er vidensdeling så svært? - om vidensorganisering og læring som kommunikation”. Det digitale nærvœr. Viden og design i nye medier. Red. Simon Heilesen. Roskilde Universitetsforlag, 2004. 13-31.

Bannon, Liam J. "Issues in Computer Supported Collaborative Learning”. Computer Supported Collaborative Learning. Red. Claire O’Malley. Springer-Verlag, 1995. 69-97.

Dalsgaard, Christian. "Pædagogisk vurdering af e-læringssystemer”. Fleksibel læering og undervisning - erfaringer, konsekvenser og muligheder med ikt. Red. Marianne Georgsen \& Jens Bennedsen. Aalborg Universitetsforlag, 2004. 239-258.

Dewey, John. Democracy and Education. The Free Press, 1916.

Dillenbourg, Pierre, Baker, M., Blaye, A. \& O’Malley, C. “The evolution of research on collaborative learning”. Learning in Humans and Machine: Towards an interdisciplinary learning science. Red. E. Spada \& P. Reiman. Oxford: Elsevier, 1996.

$<$ http://tecfa.unige.ch/tecfa/publicat/dil-papers-2/Dil.7.1.10.pdf>. 189-211. (15.2.2005)

Dunn, Rita. Artikelsamling om leringsstile. Dafolo Forlag, 2003.

Dourish, Paul, Madhu, Reddy \& Fisher, Danyel. ”Tidslighed og struktur i samarbejde”, Det digitale næervcer. Viden og design i nye medier. Red. Simon Heilesen. Roskilde Universitetsforlag, 2004. 195-213.

Engeström, Yrjö. Learning by Expanding. Orienta-Konsultit Oy, 1987.

Gardner, Howard. Frames of Mind. Basic Books, 1983.

Gardner, Howard. Multiple Intelligences - The Theory in Practice. Basic Books, 1993.

Heilesen, Simon. "CSCW som grundlag for distribueret netbaseret undervisning og læring”. Uddannelse, laring og IT - 26 forskere og praktikere gør status på området. Undervisningsministeriet, 2002. 79-86.

Lave, Jean \& Wenger, Etienne. Situated learning: Legitimate Peripheral Participation. Cambridge University Press, 1991.

Leontjev, A. Virksomhed. Bevidsthed. Personlighed. Sputnik, 1983.

O’Malley, Claire. “Designing Computer Support for Collaborative Learning”. Computer Supported Collaborative Learning. Red. C. O’Malley. Springer-Verlag, 1995. 283-297.

Qvortrup, Lars. Det lerende samfund. Gyldendal, 2001.

Roschelle, J. \& Teasley, S. D. "The construction of shared knowledge in collaborative problem solving”. Computer Supported Collaborative Learning. Red. C. O’Malley. Springer-Verlag, 1995. 69-97.

Vygotsky, L. S. Mind in Society. Harvard University Press, 1978.

Vygotsky, Lev S. (a). Tæenkning og sprog 1. Hans Reitzels Forlag, 1971. 
Tidsskrift for universiteternes efter- og videreuddannelse (ISSN 1603-5518), 2. årgang, nr. 5, 2005

Vygotsky, Lev S. (b). Tæenkning og sprog 2. Hans Reitzels Forlag, 1971.

Wenger, Etienne. Communities of Practice. Cambridge University Press, 1998. 